\title{
ROLA SAMORZĄDÓW ZAWODÓW ZAUFANIA PUBLICZNEGO W SYSTEMIE ORGANÓW OCHRONY DANYCH OSOBOWYCH
}

\begin{abstract}
Abstrakt: Artykuł rozważa formalną i materialną dopuszczalność uznania samorządów zawodów zaufania publicznego za organy nadzorcze w rozumieniu RODO, sprawujące pieczę nad przestrzeganiem przepisów o ochronie danych osobowych. Stwierdza niezbędność i proporcjonalność takiego rozwiązania w celu pogodzenia prawa do ochrony danych osobowych z obowiązkiem zachowania tajemnicy zawodowej. Opowiada się za jego wprowadzeniem w polskim prawodawstwie oraz formułuje w tym zakresie pod adresem ustawodawcy stosowne wnioski de lege ferenda.

Słowa kluczowe: rola samorządów zawodów zaufania publicznego w systemie ochrony danych osobowych, pogodzenie założeń ochrony danych osobowych z obowiązkiem zachowania tajemnicy zawodowej, nadzór nad przestrzeganiem przepisów o ochronie danych osobowych oraz nad należytym wykonywaniem zawodów zaufania publicznego, samorządy zawodów zaufania publicznego jako organy nadzorcze w rozumieniu RODO
\end{abstract}

Samorządy zawodów zaufania publicznego pełnią niewątpliwie doniosłe funkcje związane z realizacją powierzonych im zadań publicznych. Jak się powszechnie przyjmuje, są one formą wyspecjalizowanej i zdecentralizowanej terytorialnie oraz rzeczowo władzy publicznej ${ }^{1}$. Nawiązując do trójpodziału władzy państwowej,

1 Zob. np. W.J. Wołpiuk, Zawód zaufania publicznego z perspektywy prawa konstytucyjnego, [w:] Zawody zaufania publicznego a interes publiczny — korporacyjna reglamentacja versus wolność wykonywania zawodu. Materiaty z konferencji zorganizowanej przez Komisję Polityki Społecznej i Zdrowia Senatu RP przy wspótudziale Ministerstwa Pracy i Polityki Społecznej pod patronatem Marszatka Senatu RP Longina Pastusiaka, 8 kwietnia 2002 r., oprac. S. Legat, M. Lipińska, Warszawa 2002, s. 19 n.; H. Izdebski, Sprawowanie pieczy nad należytym wykonywaniem zawodu przez samorzady zawodowe, [w:] Zawody zaufania publicznego a interes publiczny..., s. 153 n.; M. Tabernacka, Zakres wykonywania zadań publicznych przez organy samorzadów zawodowych, Wrocław 2007, s. 14 n.; oraz P. Sarnecki, Pojęcie zawodu zaufania publicznego (art. 17 ust. 1 Konstytucji) na przykładzie adwokatury, [w:] Konstytucja, wybory, parlament, red. L. Garlicki, Warszawa 2000, s. 173 n. 
można też powiedzieć, że samorządy te w celu zapewnienia prawidłowej realizacji zadań zostały wyposażone we władztwo publiczne będące namiastką i odpowiednikiem władzy państwowej w sferze legislacji, egzekutywy i sądownictwa. Zgodnie $\mathrm{z}$ art. 17 ust. 1 Konstytucji $\mathrm{RP}^{2}$ reprezentują one osoby uprawnione do wykonywania zawodów zaufania publicznego oraz sprawują pieczę nad należytym wykonywaniem tych zawodów w granicach interesu publicznego i dla jego ochrony.

Niemniej jednak mimo szczególnego statusu oraz mimo że nadzór nad przestrzeganiem przepisów o ochronie danych osobowych ${ }^{3} \mathrm{w}$ dużej mierze mieści się w zakresie pieczy nad należytym wykonywaniem zawodu, ustawodawca nie uznał samorządów zawodów zaufania publicznego za organy właściwe w sprawach związanych z ochroną danych osobowych (zob. art. 1 ust. 2 pkt 4 w zw. z art. 34 ust. 1 i 2 u.o.d.o.). Zachodzi zatem konieczność przyjrzenia się bliżej, czy takie rozwiązanie jest zgodne z interesem publicznym i dobrze służy jego realizacji, czy też w świetle prawa dopuszczalne jest, aby samorządy zawodów zaufania publicznego zostały wyposażone w określone kompetencje, narzędzia i środki służące kontroli i nadzorowi nad przestrzeganiem przepisów o ochronie danych osobowych oraz czy samorządy powinny zabiegać o uzyskanie prerogatyw w powyższym zakresie.

Przede wszystkim należy zauważyć, że pojęcie danych osobowych w znacznej części wchodzi w zakres desygnatów znaczeniowych tajemnicy zawodowej, której obowiązek zachowywania jest jedną z podstawowych gwarancji należytego wykonywania zawodów zaufania publicznego. W niektórych zaś stanach faktycznych dane osobowe mogą nawet w całości pokrywać się z informacjami objętymi tajemnicą zawodową. Według art. 4 pkt 1 RODO dane osobowe oznaczają wszelkie informacje o zidentyfikowanej lub możliwej do zidentyfikowania osobie fizycznej, której dane dotyczą, w szczególności na podstawie takiego identyfikatora jak imię i nazwisko, numer identyfikacyjny, dane o lokalizacji, identyfikator internetowy bądź jeden lub kilka specyficznych czynników określających fizyczną, fizjologiczną, genetyczną, psychiczną, ekonomiczną, kulturową lub społeczną tożsamość osoby fizycznej. $Z$ kolei zgodnie na przykład $\mathrm{z}$ art. 6 Prawa o adwokaturze ${ }^{4}$ oraz art. 3 ustawy o radcach prawnych ${ }^{5}$ adwokat i radca prawny zobowiązani są bezterminowo zachować w tajemnicy wszystko, o czym dowiedzieli się w związku

2 Konstytucja Rzeczypospolitej Polskiej z dnia 2 kwietnia 1997 roku (Dz.U. z 1997 r. Nr 78, poz. 483 z późn. zm.).

3 Zob. rozporządzenie Parlamentu Europejskiego i Rady Unii Europejskiej nr 2016/679 z dnia 27 kwietnia 2016 roku w sprawie ochrony osób fizycznych w związku z przetwarzaniem danych osobowych i w sprawie swobodnego przepływu takich danych oraz uchylenia dyrektywy 95/46/WE (Dz.U.UE.L.2016.119.1 z dnia 4 maja 2016 roku), zwane ogólnym rozporządzeniem o ochronie danych osobowych lub RODO, a także ustawę z dnia 10 maja 2018 roku o ochronie danych osobowych (tekst jedn. Dz.U. z 2019 r. poz. 1781, dalej: u.o.d.o.).

${ }^{4}$ Ustawa z dnia 26 maja 1982 roku Prawo o adwokaturze (tekst jedn. Dz.U. z 2019 r. poz. 1513, dalej: u.p.a.).

${ }^{5}$ Ustawa z dnia 6 lipca 1982 roku o radcach prawnych (tekst jedn. Dz.U. z 2018 r. poz. 2115, dalej: u.r.p.). 
$\mathrm{z}$ udzieleniem pomocy prawnej, jedynie z wyjątkiem informacji udostępnianych na podstawie przepisów o przeciwdziałaniu praniu pieniędzy i finansowaniu terroryzmu oraz informacji przekazywanych na podstawie rozdziału 11a działu III Ordynacji podatkowej ${ }^{6}$. Nie powinno ulegać wątpliwości, że osoby wykonujące zawody zaufania publicznego zobligowane są przestrzegać zarówno przepisów o ochronie tajemnicy zawodowej, jak i przepisów dotyczących ochrony danych osobowych (zob. np. art. 2 ust. 1 w zw. $z$ art. 4 pkt 6 RODO $i$ art. 1 ust. 1 u.o.d.o. w zw. z art. 6 u.p.a. i art. 3 u.r.p.). Część wspólna zakresów pojęcia danych osobowych i tajemnicy zawodowej oraz odmienne reguły rządzące ochroną tych dóbr sprawiają jednak, że wymienione regulacje całkowicie lub częściowo mogą pozostawać $\mathrm{z}$ sobą w kolizji i w efekcie w większym lub mniejszym stopniu wzajemnie się eliminować. Istotnego znaczenia nabiera zatem odpowiedź na pytanie, czy w świetle unormowań RODO oraz Konstytucji RP polski ustawodawca prawidłowo uregulował w ustawie o ochronie danych osobowych kwestię rozdzielenia zakresów chronionych dóbr oraz ich zagadnienia kolizyjno-prawne?

Wskazany problem występowania kolizji między reżimem ochrony danych osobowych a tajemnicy zawodowej dostrzeżono w prawodawstwie unijnym. W odniesieniu bowiem do uprawnień organów nadzorczych do uzyskania dostępu do danych osobowych od administratorów lub podmiotów przetwarzających dane osobowe, a także dostępu do pomieszczeń zapewniono w nim, że państwa członkowskie mogą przyjmować przepisy szczegółowe mające na celu chronić obowiązek zachowania tajemnicy zawodowej lub innej tajemnicy równoważnej, o ile przewidziane w nich rozwiązania są niezbędne dla pogodzenia prawa do ochrony danych osobowych z obowiązkiem zachowania tajemnicy zawodowej. Generalnie więc wzgląd na konieczność ochrony tajemnicy zawodowej może uzasadniać odstępstwa od powszechnego modelu ochrony danych osobowych. Wyrazem takiego założenia jest art. 90 RODO, zgodnie z którym państwa członkowskie wobec administratorów lub podmiotów przetwarzających dane osobowe i podlegających jednocześnie obowiązkowi zachowania tajemnicy zawodowej lub jej równoważnym obowiązkom mogą przyjmować przepisy szczególne, określające uprawnienia organów nadzorczych w zakresie uzyskiwania dostępu do wszelkich danych osobowych i wszelkich informacji niezbędnych organowi nadzorczemu do realizacji swoich zadań, a także dostępu do wszystkich pomieszczeń oraz sprzętu i środków służących do przetwarzania danych, jeżeli jest to niezbędne i proporcjonalne w celu pogodzenia prawa do ochrony danych osobowych z obowiązkiem zachowania tajemnicy ${ }^{7}$. Wymieniony przepis, choć nie narzuca żadnych konkretnych rozwiązań,

${ }^{6}$ Ustawa z dnia 29 sierpnia 1997 r. Ordynacja podatkowa (tekst jedn. Dz.U. z 2019 r. poz. 900).

${ }^{7} \mathrm{Na}$ temat zasady proporcjonalności chronionych praw i wolności zob. bliżej J. Maliszewska-Nienartowicz, Zasada proporcjonalności w prawie Wspólnot Europejskich, Toruń 2007; oraz A. Frąckowiak-Adamska, Zasada proporcjonalności jako gwarancja swobód rynku wewnętrznego Wspólnoty Europejskiej, Warszawa 2009. Zob. również orzecznictwo Trybunału Konstytucyjnego odnoszące się do tej kwestii: Zasada proporcjonalności (w odniesieniu do prawa publiczne- 
może prowadzić do różnych form ograniczenia kontroli przestrzegania przepisów o ochronie danych osobowych lub wprowadzenia szczególnych gwarancji ochrony danych objętych powinnością zachowania tajemnicy zawodowej. Możliwość wprowadzenia takich wyjątków ma jednak zastosowanie tylko względem danych osobowych, które administrator lub podmiot przetwarzający otrzymali lub pozyskali w wyniku lub w ramach działania objętego obowiązkiem zachowania tajemnicy zawodowej. Przepisy RODO stanowią również, że jeżeli dane osobowe nie zostały pozyskane od osoby, którą identyfikują, to powinny zostać poufne zgodnie z obowiązkiem zachowania tajemnicy zawodowej (zob. art. 14 ust. 5 pkt d RODO). Przetwarzanie zaś wszelkich danych osobowych wymaga ustawowego lub umownego zobowiązania do zachowania tajemnicy (zob. art. 28 ust. 3 pkt b RODO). Ponadto należy zwrócić uwagę, że niezależnie od dopuszczalności przyjęcia przepisów ograniczających lub modyfikujących ochronę danych osobowych ze względu na konieczność zachowania tajemnicy zawodowej w niektórych przypadkach przepisy unijne same przyznają pierwszeństwo ochronie tajemnicy. Wniosek ten potwierdza motyw 164 RODO, zgodnie z którym regulacje krajowe będące odstępstwem od powszechnych standardów ochrony danych osobowych pozostają bez uszczerbku dla istniejących obowiązków państw członkowskich dotyczących ochrony tajemnicy zawodowej. Chodzi tu między innymi o ten aspekt ochrony tajemnicy zawodowej, który wiąże się z funkcją obrońcy, ponieważ przede wszystkim w tym zakresie prawo unijne zapewnia jej przestrzeganie w sposób bezwzględny i niezależny od regulacji krajowych. Poza tym w określonych sytuacjach z niektórych gwarancji prawa unijnego, na przykład z prawa do sądu, można korzystać tylko przy jednoczesnym poszanowaniu tajemnicy zawodowej (zob. np. art. 41 ust. 2b Karty Praw Podstawowych $\mathrm{UE}^{8}$ ).

Polski ustawodawca skorzystał z możliwości odrębnego uregulowania kontroli przestrzegania przepisów o ochronie danych osobowych w stosunku do podmiotów zobowiązanych do zachowania tajemnicy zawodowej, niemniej jednak rozwiązanie, które zastosował, budzi zastrzeżenia i w praktyce może być źródłem licznych wątpliwości. Kwestia kolizji reżimu ochrony danych osobowych i tajemnicy zawodowej została bowiem unormowana w ustawie o ochronie danych osobowych jedynie szczątkowo. Zgodnie z art. 64 u.o.d.o. Prezes Urzędu Ochrony Danych Osobowych (dalej: Prezes UODO) w celu realizacji swoich zadań ma prawo dostępu do informacji objętych tajemnicą prawnie chronioną, chyba że przepisy szczególne stanowią inaczej. Zatem według art. 64 u.o.d.o. samo objęcie określonych danych identyfikujących osoby fizyczne statusem tajemnicy praw-

go) w tezach Trybunatu Konstytucyjnego, Warszawa 2009, http://www.trybunal.gov.pl/index2.htm (dostęp: 19.11.2019); a także Dopuszczalność ingerencji w konstytucyjne wolności i prawa, oprac. Biuro Trybunału Konstytucyjnego, Warszawa 2013, s. 131 n., http://www.trybunal.gov.pl/index2. htm (dostęp: 19.11.2019).

${ }^{8}$ Karta Praw Podstawowych Unii Europejskiej (Dz.U.UE.C.2007.303.1 z dnia 14 grudnia 2007 roku). 
nie chronionej nie wyłącza ich kontroli ze strony Prezesa UODO. Konieczne jest istnienie przepisów szczególnych, które uniemożliwiają dostęp do takich danych z uwagi na ochronę oznaczonej tajemnicy. Za takie przepisy można przykładowo uznać unormowania nakazujące adwokatom i radcom prawnym zachowanie $\mathrm{w}$ tajemnicy wszystkiego, o czym dowiedzieli się w związku z udzieleniem pomocy prawnej (zob. art. 6 ust. 1 u.p.a. oraz art. 3 ust. 3 u.r.p.), a także wprowadzone niedawno unormowania wyłączające stosowanie niektórych przepisów RODO podyktowane wyraźnie ochroną tajemnicy zawodowej ${ }^{9}$ (zob. art. 16a ust. 1 i 2 u.p.a. oraz art. 5a ust. 1 i 2 u.r.p.). Mimo nawet ustawowego przesądzenia, że obowiązek zachowania tajemnicy zawodowej adwokata i radcy prawnego nie ustaje w przypadku, gdy z żądaniem ujawnienia informacji uzyskanych w związku z udzieleniem przez nich pomocy prawnej występuje Prezes UODO (zob. art. 16b u.p.a. i art. 5 b u.r.p.), wobec bardzo szerokiego ujęcia zakresu tajemnicy zawodowej problem jej ujawnienia wciąż istnieje. Nadal brakuje bowiem generalnego wyłączenia spod kontroli Prezesa UODO danych osobowych przetwarzanych przez jej dysponentów zobowiązanych do ochrony tajemnicy zawodowej, a także przez jednostki organizacyjne $\mathrm{z}$ ich udziałem. W praktyce niełatwo natomiast oddzielić dane osobowe tworzące przedmiot tajemnicy zawodowej i dane nią nieobjęte, zwłaszcza jeśli są z sobą funkcjonalnie powiązane i łącznie przetwarzane. Należy przy tym zauważyć, że nie ma przepisów ani jakichkolwiek innych norm, które nakazywałyby oddzielne przechowywanie różnego rodzaju danych w ten sposób, aby można było je odrębnie i niezależnie od siebie przeglądać. Zabieg taki z wielu względów byłby zresztą niemożliwy do obiektywnego i konsekwentnego przeprowadzenia, ponieważ gromadzenie różnych co do charakteru danych bezpośrednio lub pośrednio może zawsze służyć wykonywaniu czynności zawodowych. Dotyczy to w szczególności świadczenia pomocy prawnej przez adwokatów i radców prawnych, którzy nierzadko dokonują czynności zawodowych na podstawie akt danej sprawy, a więc ogółu różnych i niekoniecznie usystematyzowanych informacji związanych z powierzoną im sprawą. Tymczasem według ogólnych reguł Prezes UODO w celu realizacji swoich zadań jest uprawniony do wejścia do lokalu kancelarii oraz wszelkich innych pomieszczeń związanych ze świadczeniem pomocy prawnej, choćby znajdowały się one w miejscu zamieszkania dysponentów tajemnicy zawodowej, a także w granicach swoich uprawnień może on lustrować znajdujący się w miejscu kontroli sprzęt i środki służące do przetwarzania danych osobowych, na przykład komputery, oprogramowanie, serwery, telefony, rutery, repertoria, wizytowniki itp. (zob. art. 58 ust. 1 pkt e i f RODO). Poza tym należy zwrócić uwagę, że ustawodawca w stosunku do innych zawodów zaufania publicznego zobowiązanych do ochrony tajemnicy zawodowej (na przykład rzeczni-

9 Na temat pojęcia tajemnicy zawodowej i kształtowania się jej zakresu zob. np. M. Kucharczyk, Charakter prawny tajemnicy adwokackiej w ujęciu historycznym, „Czasopismo Prawa Karnego i Nauk Penalnych" 2007, z. 1, s. 57 n.; oraz M. Swora, Tajemnica adwokacka w świetle wybranych przepisów ustawy o ochronie danych osobowych, „Palestra” 2004, nr 3-4, s. 76 n. 
ków patentowych) nie przewidział żadnych gwarancji respektowania ich tajemnicy w związku z kontrolą Prezesa UODO, nawet takich niedostatecznych jak ma to miejsce w przypadku adwokatów i radców prawnych. Umożliwienie dostępu Prezesowi UODO do danych osobowych przetwarzanych w związku z wykonywaniem zawodów zaufania w praktyce może zatem prowadzić do nieuprawnionego ujawnienia tajemnicy zawodowej.

Obiektywne trudności w rozgraniczeniu zakresów danych osobowych oraz danych objętych tajemnicą zawodową stwarza wielką niepewność co do prawidłowego stosowania prawa. Oceny sytuacji nie ułatwiają również sankcje, jakie wiążą się z naruszeniem przepisów zarówno o ochronie danych osobowych, jak i o ochronie tajemnicy zawodowej. Podczas czynności kontrolnych nie powinno się wywierać presji na ujawnienie danych, które prowadzą lub z dużym prawdopodobieństwem mogą prowadzić do naruszenia tajemnicy zawodowej. Dysponenci tajemnicy zawodowej w przypadku jej ujawnienia mogą odpowiadać nie tylko cywilnie z tytułu naprawienia wyrządzonej szkody, ale również dyscyplinarnie oraz karnie na podstawie art. $266 \S 1$ k.k. ${ }^{10}$ Jednocześnie jednak niezależnie od bardzo wysokich kar pieniężnych za naruszenie przepisów o ochronie danych osobowych nieuzasadniona odmowa udostępnienia danych osobowych może zostać zakwalifikowana jako udaremnianie lub utrudnianie kontroli przestrzegania przepisów o ochronie danych osobowych, co wypełnia znamiona czynu karalnego stypizowanego w art. 108 u.o.d.o. Natomiast oba wymienione czyny karalne podlegają jednakowym sankcjom, mianowicie grzywnie, karze ograniczenia wolności albo pozbawienia wolności do lat 2 . Z punktu widzenia społecznej wagi oraz rangi chronionych dóbr wskazane rozwiązanie budzi zasadnicze wątpliwości, gdyż nie koresponduje ze szczególną ochroną tajemnicy zawodowej oraz jej pierwszeństwem, któremu ustawodawca dał stosowny wyraz w art. 64 u.o.d.o. Niejednoznaczność sankcji oraz ich znaczna dotkliwość utrudnia dysponentom tajemnicy zawodowej podejmowanie właściwych decyzji podczas kontroli przestrzegania przepisów. Mogłoby się wydawać, że w sprawach wątpliwych wszelkie niejasności powinny być rozstrzygane na korzyść ochrony tajemnicy zawodowej jako szczególnego dobra prawnego w stosunku do danych osobowych, niemniej jednak obowiązujące przepisy nie tworzą dostatecznych podstaw do takiej interpretacji. Przeciwnie ochronę tajemnicy zawodowej w dużym stopniu traktują one jako wyjątek, który zgodnie z regułami wykładni aktów prawnych nie może prowadzić do rozszerzania zakresu swego zastosowania. W tym stanie rzeczy istnieje realna obawa tworzenia się u dysponentów tajemnicy zawodowej postaw konformistycznych, które jednak nie powinny być tolerowane przez samorządy zawodów zaufania publicznego.

$\mathrm{Z}$ punktu widzenia standardów ochrony tajemnicy zawodowej istotne wątpliwości budzi już sam dostęp osób trzecich do wszelkich urządzeń i środków służących do przetwarzania danych. Jeśli weźmie się pod uwagę również łatwość

10 Ustawa z dnia 6 czerwca 1997 roku Kodeks karny (tekst jedn. Dz.U. z 2018 r. poz. 1600). 
zapoznania się z danymi chronionymi tajemnicą zawodową, a także możliwość ich szybkiego i niepostrzeżonego skopiowania lub zwielokrotnienia za pomocą innych technik, można dojść do wniosku, że polski ustawodawca przy wdrażaniu nowych przepisów o ochronie danych osobowych zlekceważył problem zapewnienia realnych gwarancji ochrony tajemnicy zawodowej. Niepokojąca jest zwłaszcza pewna tendencja do relatywizowania tajemnicy zawodowej i traktowania jej nie jako podstawowego standardu demokratycznego państwa prawa, lecz wyjątkowego i coraz bardziej wątpliwego przywileju. Tymczasem należy przypomnieć, że stanowi ona fundament niezależności i konstrukcyjny element prawa do sądu, który powszechnie uznawany jest za konieczny do zapewnienia należytej ochrony konstytucyjnych praw i wolności osób korzystających z pomocy prawnej (zob. art. 2 w zw. z art. 45 ust. 1 Konstytucji RP) ${ }^{11}$. Co istotne, tajemnica zawodowa lub inna prawnie chroniona tajemnica jest również niezbędna do urzeczywistnienia niektórych gwarancji dotyczących prawa do prywatności oraz ochrony danych osobowych. Należy podkreślić, że zarówno RODO, jak i żadne inne przepisy o ochronie danych osobowych nie modyfikują ani w inny sposób formalnie nie ograniczają tajemnicy zawodowej. Regulacje te formułują różne gwarancje ochrony danych osobowych, jednakże tylko w takim zakresie, w jakim można je zrealizować bez ingerencji w treść prawa do tajemnicy zawodowej lub tajemnicy jej równoważnej (zob. np. art. 14 ust. 5 pkt d oraz art. 28 ust. 3 pkt b RODO; por. art. 90 ust. 1 RODO).

Zważywszy na istniejące problemy interpretacyjne związane z obiektywnymi trudnościami rozdzielenia różnych powinności dotyczących ochrony tajemnicy zawodowej oraz danych osobowych, de lege ferenda należy postulować powierzenie samorządom zawodów zaufania publicznego nadzoru i kontroli przestrzegania przepisów o ochronie danych osobowych. Zadania w tym zakresie mieszczą się w kompetencji czuwania nad należytym wykonywaniem zawodów zaufania publicznego i w pewnej mierze mogą również służyć wzmocnieniu ochrony tajemnicy zawodowej. RODO nie tylko nie sprzeciwia się takiemu rozwiązaniu, ale zdaje się mu wyraźnie sprzyjać. Motyw 50 RODO wskazuje bowiem na konieczność zabronienia przetwarzania danych osobowych, jeżeli jest to niezgodne z prawnym, zawodowym lub innym wiążącym obowiązkiem zachowania tajemnicy, natomiast prawidłowa realizacja takiej powinności nie jest możliwa bez zagwarantowania udziału samorządów zawodowych. Poza tym zgodnie z art. 51 RODO państwa członkowskie zapewniają, że za monitorowanie przestrzegania przepisów o ochronie danych osobowych będzie odpowiadał co najmniej jeden niezależny organ publiczny. Nie ma więc żadnych przeszkód, aby kontrolą prawidłowości stosowania przepisów o ochronie danych osobowych zajmowało się kilka różnych niezależ-

11 Na temat znaczenia tajemnicy zawodowej dla realizacji praw i wolności konstytucyjnych zob. bliżej W. Marchwicki, Tajemnica adwokacka. Analiza konstytucyjna, Warszawa 2015, s. 13 n. oraz cyt. tam literatura i orzecznictwo. 
nych organów publicznych ${ }^{12}$. W świetle art. 51 RODO dopuszczalne wydaje się powierzenie takiego zadania zarówno dwóm, jak i większej liczbie niezależnych organów publicznych i to nie tylko w sposób funkcjonalnie podzielny, lecz także niepodzielny i wyłączny w stosunku do określonej kategorii administratorów oraz podmiotów przetwarzających dane osobowe. Zważywszy na konieczność zabezpieczenia tajemnicy zawodowej, nadzór i kontrolę nad przestrzeganiem przepisów o ochronie danych osobowych względem dysponentów tajemnicy prawnie chronionej mogą sprawować samorządy zawodów zaufania publicznego. Samorządy te są nie tylko niezależnymi organami publicznymi ${ }^{13}$ realizującymi zadania publiczne dotyczące nadzoru nad należytym wykonywaniem określonych zawodów, ale są również w naturalny sposób predysponowane do monitorowania i kontroli działalności administratorów danych osobowych oraz podmiotów przetwarzających takie dane w związku z wykonywaniem poszczególnych zawodów zaufania publicznego. Naruszenia przepisów o ochronie danych osobowych podczas dokonywania czynności zawodowych, w szczególności jeśli polegają one na świadczeniu pomocy prawnej, są przejawem nienależytego wykonywania zawodu, do którego nadzoru, zgodnie z art. 17 ust. 1 Konstytucji RP, zostały instytucjonalnie powołane samorządy zawodów zaufania publicznego ${ }^{14}$. Ponadto samorządy zawodów zaufania publicznego dysponują niezbędnymi i przygotowanymi merytorycznie kadrami, a także mają dobrze rozwinięte formy współpracy międzynarodowej, w tym zwłaszcza w ramach państw członkowskich Unii Europejskiej, co mogłoby efektywnie służyć ochronie danych osobowych oraz ułatwianiu ich swobodnego przepływu na rynku wspólnotowym. Proponowane rozwiązanie przyczyniłoby się więc nie tylko do skuteczniejszego zwalczania nadużyć przy przetwarzaniu danych osobowych objętych obowiązkiem zachowania tajemnicy zawodowej, lecz także do pewnego ujednolicenia standardów ochrony tajemnicy zawodowej oraz niezbędnej parametryzacji techniczno-organizacyjnej działalności związanej z wykonywaniem zawodów zaufania publicznego ${ }^{15}$.

12 Prawidłowość tę w pewnym sensie potwierdzają rozwiązania przyjęte w ustawie $\mathrm{z}$ dnia 21 lutego 2019 roku o zmianie niektórych ustaw w związku z zapewnieniem stosowania rozporządzenia Parlamentu Europejskiego i Rady (UE) 2016/679 z dnia 27 kwietnia 2016 roku w sprawie ochrony osób fizycznych w związku z przetwarzaniem danych osobowych i w sprawie swobodnego przepływu takich danych oraz uchylenia dyrektywy 95/46/WE (ogólne rozporządzenie o ochronie danych) — Dz.U. z 2019 r. poz. 730.

13 Należy podkreślić, że niezależność samorządów zawodów zaufania publicznego wywodzi się z idei samorządności. Jest ona również manifestowana wprost w wielu przepisach (zob. np. art. 40 ust. 1 u.r.p. oraz art. 47 ust. 3 ustawy z 5 lipca 1996 roku o doradztwie podatkowym — tekst jedn. Dz.U. z 2019 r. poz. 283).

14 H. Izdebski, op. cit., s. 153 n.

15 Na marginesie należy jednak zauważyć, że o ile ustandaryzowanie wymogów technicznych i organizacyjnych w odniesieniu do obowiązku zachowania tajemnicy poszczególnych zawodów zaufania publicznego jest jak najbardziej pożądane, o tyle standaryzacja ochrony danych osobowych z pewnością nie może mieć charakteru zupełnego, ponieważ poziom ochrony danych osobowych w każdym 
Podczas prac nad ustawą o ochronie danych osobowych z dnia 10 maja 2018 roku nie podejmowano kwestii powierzenia samorządom zawodów zaufania publicznego nadzoru nad przestrzeganiem jej przepisów oraz regulacji RODO. Samorządy zawodów zaufania publicznego nie czyniły też żadnych starań w tym kierunku, jednak w pewnej mierze było to spowodowane dążeniem do podmiotowego wyłączenia dysponentów tajemnicy zawodowej spod reżimu tych unormowań. Środowiska samorządowe od samego początku prac nad wdrożeniem RODO dostrzegały bowiem problem kolizji przepisów o ochronie danych osobowych z założeniami ochrony tajemnicy zawodowej. Obecnie zaś wobec niedostatecznych i dość enigmatycznie sformułowanych gwarancji ochrony tajemnicy zawodowej w ustawie o ochronie danych osobowych z dnia 10 maja 2018 roku, a także niebezpieczeństwa nieidentyfikowania tajemnicy, istniejącej praktyki zawężania jej zakresu oraz ryzyka ujawniania, samorządy zawodów zaufania publicznego powinny zjednoczyć się wokół idei powierzenia im przez ustawodawcę kontroli przestrzegania przepisów o ochronie danych osobowych. Nie można bezkrytycznie podzielić optymistycznego zapatrywania pomysłodawców art. 64 wymienionej ustawy, że Prezes UODO nie ma dostępu do danych osobowych, które są objęte tajemnicą zawodową, ponieważ w dużej mierze nie da się dokonać racjonalnego rozdzielenia takich informacji. Więc mimo że Prezes UODO formalnie nie ma uprawnienia w dostępie do danych o statusie tajemnicy zawodowej, to jednak faktycznie podczas jego czynności kontrolnych może dochodzić do ich ujawnienia. Sprzyjają temu nie tylko dotkliwsze sankcje przewidziane za naruszenie przepisów o ochronie danych osobowych, lecz także wkomponowany w nie mechanizm zawężający ujmowanie tajemnicy zawodowej. Zakres obowiązku zachowania tajemnicy zawodowej w przepisach może być w różny sposób ukształtowany, stosownie do potrzeb podyktowanych zapewnieniem należytego wykonywania danego zawodu. Przykładowo w wypadku adwokatów i radców prawnych tajemnica zawodowa rozciąga się na wszystkie informacje pozyskane w związku z udzielaniem pomocy prawnej niezależnie od ich konkretnego źródła. Zatem obejmuje ona także dane, które zebrano w związku z przygotowywaniem się do świadczenia pomocy prawnej, chociażby ostatecznie nie doszło do jej zlecenia, a także dane, które okazały się później nieprzydane do udzielenia pomocy prawnej. Na zakres obowiązku zachowania tajemnicy zawodowej nie powinny wpływać żadne inne względy, jeśli nie mają związku z pragmatyką zawodową, także wówczas gdy dotyczą ochrony danych osobowych. Oznacza to, że przepisy regulujące ochronę danych osobowych oraz praktyka ich stosowania nie mogą wpływać ograniczająco na zakres obowiązku zachowania tajemnicy zawodowej. W istniejącym stanie prawnym ważnym problemem jest jednak rozwiązanie, według którego o zakresie kontroli przestrzegania przepisów o ochronie danych osobowych oraz

razie powinien być adekwatny do konkretnej działalności, a zwłaszcza jej skali, natężenia zagrożeń czy rodzaju przetwarzanych danych osobowych (por. art. 5 RODO). 
ich naruszeniu, a zarazem o statusie danych objętych tajemnicą zawodową decyduje Prezes UODO, a więc organ, który nie ma kompetencji do rozstrzygania, czy określone dane osobowe są przetwarzane w związku z należytym wykonywaniem danego zawodu oraz czy są objęte tajemnicą zawodową ${ }^{16}$. W świetle art. 17 ust. 1 Konstytucji RP kompetencje w tym zakresie mają samorządy zawodów zaufania publicznego, które de lege ferenda powinny przejąc nadzór nad przestrzeganiem przepisów o ochronie danych osobowych w stosunku do swoich członków, a także kontrolowanych przez nich jednostek organizacyjnych, w których wykonują oni swój zawód. Zaproponowane rozwiązanie nie przekreśla możliwości wywierania wpływu Prezesa UODO na kształtowanie polityki ochrony danych osobowych, ponieważ zgodnie z art. 51 ust. 2 i 3 w zw. z art. $60 \mathrm{n}$. RODO każdy organ nadzorczy przyczynia się do spójnego stosowania przepisów w całej Unii Europejskiej i w tym celu zobowiązany jest do współpracy między sobą oraz z Komisją Europejską w celu wypracowania porozumienia oraz do wzajemnej pomocy. Jeśli zaś w państwie członkowskim ustanowiono więcej niż jeden organ nadzorczy, państwo to wskazuje, który z nich jest organem głównym i reprezentującym te organy w Europejskiej Radzie Ochrony Danych, oraz ustala mechanizm zapewniający przestrzeganie przez pozostałe organy przepisów art. $63 \mathrm{n}$. RODO o mechanizmie spójności. Należy bowiem zaznaczyć, że według treści tych przepisów Europejska Rada Ochrony Danych została wyposażona w różne środki, zarówno o charakterze opiniodawczym, jak i decyzyjnym, których zasadniczym celem jest zapewnienie jednolitego stosowania RODO we wszystkich państwa członkowskich (zob. art. 57-59 RODO). Przy wielości organów nadzorczych Prezes UODO mógłby zatem odgrywać rolę organu wiodącego i reprezentującego pozostałe organy w Europejskiej Radzie Ochrony Danych.

Warto ponadto zwrócić uwagę, że RODO przewiduje wiele różnych gwarancji niezależności organów nadzorczych. Zgodnie z art. 52 RODO każdy organ nadzorczy podczas wypełniania swoich zadań działa w sposób w pełni niezależny. Organy nadzorcze mogą mieć charakter zarówno jednoosobowy, jak i kolegial$n y^{17}$. Niezależnie od tego wszyscy członkowie organów są wolni od jakichkolwiek wpływów zewnętrznych, nie mogą zwracać się do nikogo o instrukcje ani ich od nikogo przyjmować. Mają również obowiązek powstrzymywania się od wszelkich czynności i zajęć zarówno zarobkowych, jak i niezarobkowych, które mogłyby kolidować z należytym wykonywaniem swoich zadań. Każde państwo członkowskie zapewnia również, że organy nadzorcze będą dysponować zasobami kadrowymi, technicznymi, finansowymi, lokalowymi oraz infrastrukturą

16 Należy tu zwłaszcza zwrócić uwagę na art. 97 u.o.d.o., zgodnie z którym ustalenia prawomocnej decyzji Prezesa UODO o stwierdzeniu naruszenia przepisów o ochronie danych osobowych wiążą sąd w postępowaniu o naprawienie szkody wyrządzonej przez takie naruszenie.

17 P. Litwiński, P. Barta, Komentarz do art. 57, [w:] Rozporzadzenie UE w sprawie ochrony osób fizycznych w związu z przetwarzaniem danych osobowych i swobodnym przeptywem takich danych. Komentarz, red. P. Litwiński, Warszawa 2018. 
niezbędną do skutecznego wypełniania wszystkich swoich zadań i uprawnień. Co istotne, każdy organ nadzorczy ma dysponować odrębnym publicznym budżetem rocznym, który może być częścią ogólnego budżetu państwowego lub krajowego i ma podlegać kontroli finansowej w sposób nienaruszający jego niezależności. Zgodnie z art. 53 RODO członkowie organu nadzorczego powinni być powoływani w przejrzystej procedurze nie tylko przez parlament, rząd, głowę państwa, lecz także przez inny niezależny organ, którym może być wskazany ustawowo organ poszczególnego samorządu zawodów zaufania publicznego. Każdy członek organu nadzorczego powinien mieć kwalifikacje, doświadczenie i umiejętności, które są niezbędne do wypełniania swoich obowiązków i uprawnień. Członek organu może zostać odwołany ze stanowiska, tylko gdy dopuścił się poważnego uchybienia lub przestał spełniać warunki niezbędne do wypełniania swoich kompetencji. RODO precyzuje również główne zasady ustanawiania i funkcjonowania organu nadzorczego, jakie powinny przyjąć państwa członkowskie w swych ustawodawstwach, w szczególności dotyczące kwalifikacji członków organów nadzorczych, ich nieusuwalności, długości trwania kadencji organów nadzorczych i możliwości jej przedłużania, ograniczeń w podejmowaniu aktywności kolidujących z należytym wykonywaniem obowiązków organu nadzorczego oraz zachowania tajemnicy służbowej przez członków i personel organu nadzorczego (zob. art. 54 RODO). Nie ma żadnych przeszkód, aby każda $\mathrm{z}$ tych gwarancji miała zastosowanie do samorządów zawodów zaufania publicznego.

Organy nadzorcze są właściwe do realizowania zadań i wykonywania uprawnień powierzonych im zgodnie z RODO na terytorium swojego państwa członkowskiego. Nie mają jednak kompetencji do nadzorowania operacji przetwarzania danych przez sądy w ramach sprawowania przez nie wymiaru sprawiedliwości (zob. art. 55 ust. 1 i 3 RODO). Wyłączenie to dotyczy również czynności zawodów zaufania publicznego, które są związane z wykonywaniem władzy publicznej (chodzi na przykład o czynności sprawowania funkcji w orzecznictwie dyscyplinarnym oraz w innych organach samorządu zawodowego). RODO nie ma bowiem zastosowania do przetwarzania danych osobowych w odniesieniu do działalności nieobjętej prawem Unii Europejskiej, a taką jest niewątpliwe działalność związana z wykonywaniem władzy publicznej (zob. art. 2 ust. 2 pkt a RODO w związku $\mathrm{z}$ art. $51 \mathrm{TFUE}^{18}$ ). Trzeba jednak pamiętać, że wskazane wyłączenie ma charakter przedmiotowy, a nie podmiotowy i jako wyjątek nie może podlegać wykładni rozszerzającej, chyba że chodzi o czynności, których nie da się wyodrębnić z działalności związanej z wykonywaniem władzy publicznej i odrębnie klasyfikować ${ }^{19}$. RODO precyzuje zadania i uprawnienia organów nadzorczych w sposób samoistny i niezależny od regulacji państw członkowskich, które mogą przyznawać im także

18 Traktat o funkcjonowaniu Unii Europejskiej, dalej: Traktat lub TfUE (Dz.U. z 2004 r. $\mathrm{Nr} 90$, poz. 864/2 z późn. zm.).

19 Zob. w tej mierze np. orzeczenie ETS z dnia 20 czerwca 1974 roku w sprawie J. Reaners, C-2/74, LEX nr 137993. 
inne kompetencje. Unormowania zawarte w art. 57-59 RODO mają więc w tym zakresie charakter minimalny i są bezpośrednio stosowane w prawodawstwach krajowych (zob. art. 99 RODO w zw. z art. 288 TfUE). W przypadku istnienia wielości organów nadzorczych na terytorium danego państwa członkowskiego prawo krajowe powinno określać podział kompetencji pomiędzy nimi. Z uwagi na treść art. 55 ust. 1 RODO wydaje się, że każdy z organów powinien być wyłącznie właściwy w odniesieniu do spraw określonej kategorii administratorów i podmiotów przetwarzających dane osobowe, natomiast podział rzeczowy ich kompetencji jest niedopuszczalny, chyba że chodzi o zadania i uprawnienia, które przyznano mu dodatkowo na podstawie prawa krajowego państwa członkowskiego. W świetle przepisów RODO nie ma natomiast przeszkód, aby podzielić kompetencje organów nadzorczych według właściwości funkcjonalnej (por. art. 51 ust. 3 RODO). Prezes UODO może zatem pełnić funkcję organu głównego nie tylko w sprawach transgranicznych (zob. art. 56 RODO), lecz także w zakresie wynikającym z przepisów polskiego ustawodawstwa również w sprawach wewnątrzkrajowych, z tym że do stosowania mechanizmu spójności, o którym mowa w art. 63 n. RODO, zobowiązany jest każdy nadzorczy ${ }^{20}$.

Na gruncie zarówno RODO, jak i Konstytucji RP powierzenie samorządom zawodów zaufania publicznego kompetencji w zakresie nadzoru i kontroli nad przestrzeganiem przepisów o ochronie danych osobowych przez dysponentów tajemnicy zawodowej jest rozwiązaniem niezbędnym i proporcjonalnym w celu pogodzenia prawa do ochrony danych osobowych z obowiązkiem zachowania tajemnicy. Z uwagi na szeroki zakres tajemnicy zawodowej i konieczność jej ochrony zjednej strony jako gwarancji realizacji konstytucyjnych praw i wolności, z drugiej zaś jako gwarancji należytego wykonywania danego zawodu zaufania publicznego w wielu przypadkach nie ma ani racjonalnej, ani jednoznacznej możliwości rozdzielenia zakresów tajemnicy oraz danych osobowych nieobjętych obowiązkiem jej zachowania, zwłaszcza jeśli ma ona dokonywać się jedynie na potrzeby kontroli przestrzegania przepisów o ochronie danych osobowych. Takie nierzadko sztuczne dzielenie wskazanych danych nie tylko wpływa na zwiększenie kosztów prowadzenia działalności, lecz także istotne zwiększa ryzyko nieuprawnionego ujawnienia tajemnicy zawodowej Prezesowi UODO oraz jego personelowi. Z kolei wyłączenie spod kontroli danych osobowych objętych obowiązkiem zachowania tajemnicy zawodowej obniża skuteczność realizacji ochrony danych osobowych przetwarzanych przez osoby wykonujące zawody zaufania publicznego oraz przez jednostki organizacyjne, w których mogą oni wykonywać czynności zawodowe. Samorządy zawodów zaufania publicznego z tytułu powierzonego im nadzoru nad należytym wykonywaniem tych zawodów mogą natomiast zapoznawać się

20 Por. P. Kozik, Zakres swobody regulacyjnej państw członkowskich przy wdrażaniu ogólnego rozporzadzenia o ochronie danych osobowych do prawa krajowego, „Europejski Przegląd Sądowy" 2017, nr 5, s. 18 n. 
z treścią tajemnicy zawodowej swoich członków. Wprawdzie pomimo że brakuje wyraźnej podstawy prawnej do traktowania znoszenia tego nadzoru jako kontratypu wyłączającego bezprawność ujawnienia tajemnicy zawodowej, samorządy zawodów zaufania publicznego nie mają takich ograniczeń w dostępie do tajemnicy zawodowej, jakie w obecnym stanie prawnym są adresowane do Prezesa UODO i podległych mu służb. Zważywszy jednocześnie, że na podstawie ustawowo przy-

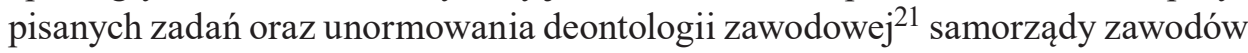
zaufania publicznego mogą, przynajmniej względem swoich członków, nadzorować przestrzeganie przepisów dotyczących ochrony danych osobowych, to wydaje się, że powinny one również zostać uznane przez polskiego ustawodawcę za organy nadzoru w rozumieniu tych przepisów. Konieczne jest jednak wyposażenie samorządów zawodów zaufania publicznego w odpowiednie środki i narzędzia umożliwiające wypełnianie zadań i uprawnień przewidzianych w RODO. W tym celu niezbędna jest stosowna nowelizacja ustawy o ochronie danych osobowych oraz ustaw normujących wykonywanie poszczególnych zawodów zaufania publicznego. Wskazane rozwiązanie jest nie tylko formalnie zgodne z RODO, ale również z punktu widzenia zasady proporcjonalności bardziej adekwatnym i efektywnym wyważeniem prawa do ochrony danych osobowych oraz obowiązku zachowania tajemnicy zawodowej.

\section{THE ROLE OF PROFESSIONS OF PUBLIC TRUST ASSOCIATIONS IN THE SYSTEM OF PERSONAL DATA PROTECTION}

\section{Summary}

The article contemplates the formal and substantive admissibility of the recognition of the professions of public trust associations as the supervisory authorities under the provisions of GDPR, which supervise the compliance with the laws regarding personal data protection. The article states the necessity and proportionality of the suggested solution in order to reconcile the right to the protection of personal data with the duty to maintain professional secrecy. It is in favour of the implementation of this solution into Polish legislation and formulates appropriate remarks to the legislator about the law as it should stand.

Keywords: professions of public trust associations, personal data protection, professional secrecy, supervision over proper performance of public trust professions, supervisory authorities in personal data protection, GDPR

21 W uproszczeniu można powiedzieć, że to zespół norm pozaprawnych o charakterze moralnym, odnoszący się do prawidłowego wykonywania danego zawodu. Normy etyczne w praktyce często jednak łączone są z normami o charakterze prakseologicznym i w powiązaniu z nimi określane są często mianem deontologii zawodowej. 


\section{BIBLIOGRAFIA}

Frąckowiak-Adamska A., Zasada proporcjonalności jako gwarancja swobód rynku wewnętrznego Wspólnoty Europejskiej, Warszawa 2009.

Izdebski H., Sprawowanie pieczy nad należytym wykonywaniem zawodu przez samorzady zawodowe, [w:] Zawody zaufania publicznego a interes publiczny — korporacyjna reglamentacja versus wolność wykonywania zawodu. Materiaty z konferencji zorganizowanej przez Komisję Polityki Społecznej i Zdrowia Senatu RP przy współudziale Ministerstwa Pracy i Polityki Społecznej pod patronatem Marszatka Senatu RP Longina Pastusiaka, 8 kwietnia 2002 r., oprac. S. Legat, M. Lipińska, Warszawa 2002.

Kozik P., Zakres swobody regulacyjnej państw członkowskich przy wdrażaniu ogólnego rozporządzenia o ochronie danych osobowych do prawa krajowego, „Europejski Przegląd Sądowy" 2017, nr 5.

Kucharczyk M., Charakter prawny tajemnicy adwokackiej w ujęciu historycznym, „Czasopismo Prawa Karnego i Nauk Penalnych" 2007, z. 1.

Litwiński P., Barta P., Komentarz do art. 57, [w:] Rozporządzenie UE w sprawie ochrony osób fizycznych $w$ zwiazku z przetwarzaniem danych osobowych $i$ swobodnym przeplywem takich danych. Komentarz, red. P. Litwiński, Warszawa 2018.

Maliszewska-Nienartowicz J., Zasada proporcjonalności w prawie Wspólnot Europejskich, Toruń 2007.

Marchwicki W., Tajemnica adwokacka. Analiza konstytucyjna, Warszawa 2015.

Sarnecki P., Pojęcie zawodu zaufania publicznego (art. 17 ust. 1 Konstytucji) na przykladzie adwokatury, [w:] Konstytucja, wybory, parlament, red. L. Garlicki, Warszawa 2000.

Swora M., Tajemnica adwokacka w świetle wybranych przepisów ustawy o ochronie danych osobowych, „Palestra” 2004, nr 3-4.

Tabernacka M., Zakres wykonywania zadań publicznych przez organy samorządów zawodowych, Wrocław 2007.

Wołpiuk W.J., Zawód zaufania publicznego z perspektywy prawa konstytucyjnego, [w:] Zawody zaufania publicznego a interes publiczny - korporacyjna reglamentacja versus wolność wykonywania zawodu. Materiaty z konferencji zorganizowanej przez Komisję Polityki Społecznej i Zdrowia Senatu RP przy wspótudziale Ministerstwa Pracy i Polityki Społecznej pod patronatem Marszatka Senatu RP Longina Pastusiaka, 8 kwietnia 2002 r., oprac. S. Legat, M. Lipińska, Warszawa 2002. 